\title{
Cooperative principle in Facebook interaction among collegian
}

\author{
Lusi Elisa $^{\mathrm{a}, 1, *}$, Rina Wahyuni ${ }^{\mathrm{b}, 2}$ \\ a,b STKIP Tunas Palapa, Bandar Jaya Bar., Kec. Terbanggi Besar, Kabupaten Lampung Tengah, Lampung 34163, Indonesia \\ ${ }^{1}$ lusielisa33@gmail.com*; ${ }^{2}$ rhyna93@gmail.com \\ * corresponding author
}

\section{ARTICLE INFO}

Article history

Received 16 December 2019

Revised 23 March 2020

Accepted 16 August 2020

Available Online 15 January 2021

Keywords

disobedience

sociological approach

around the world in 80 days

\section{ABSTRACT}

One of the main principles guiding people's communication is the cooperative principle by American linguist Grice. The use of cooperative principle helps people to increase their flexibility and accuracy. The analysis of cooperative principle in a text or conversation shall be the learning for people to communicate well using language with each other. The paper aimed to find out whether the participants under study followed or violated the maxims proposed by Grice. Besides, it was to identify whether the cooperative principles become the participants' orientation or mere redundant rules. The research employed a descriptive qualitative research of which the data were obtained from the conversation among six workmates in a Flary group discussion on Facebook page. The research founds that the conversation followed and violated the maxims by Grice. Maxim of quantity was the most frequently used by the participants (12.77\%). Interestingly, it was also the most frequently violated $(63.8 \%)$. Despite the violation occurred in the interactions, the conversation was smooth. When the speakers realized about the cooperative principles they had to obey, the conversation became more relaxed, effective, and efficient.

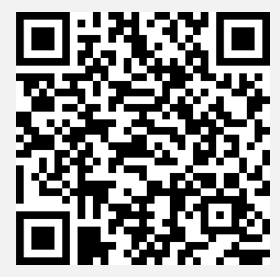

This is an open access article under the CC-BY-SA license.

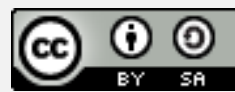

\section{Introduction}

The communication main goal is to achieve understanding among speakers. In it, interaction is meaningless when there is no communication. Cooperative conversation can work even when the speakers are not involved in social cooperation. For example, people can exchange arguments with other people but still manage the cooperation to reach an agreement. It is the evident of cooperative communication. Grice defines that in a number of communication maxims, there are conditions that we need to accept. Maxims are seen at the first sight of rules, but they emerge more broken than the rule that is used in grammar or phonology. The study analyzed The present study analyzed how cooperative principles used in a Facebook group of English Education Master's Degree (Magister Pendidikan Bahasa Inggris-MPBI) students of Lampung University 2016. The analysis included the kinds of maxims followed and violated by the participants. 


\subsection{Grice's Cooperative Principle}

Grice as cited in Finch (2000:159) argues that the cooperation people made in communication process reduces the misunderstanding between the speakers. Cooperative Principles (CP) were investigated and the basic concepts underlying the CP and Maxims were outlined. Previously, Austin (1962) and Searle (1969) concerned much on the relationship of direct and indirect speech acts and also in the concept of the things that you could "do" with the others words "language is as much as an action opening the door and closing the window". The learning of such a theory use is shifted away from the original value of approach and the truth on sense and also the references for the source meaning (e.g. Frege and Russell). It also had the growing interest of the meaning in utterance rather than just a sentence. It confirmed that the level of discourse is one to one mapping between the linguist form and utterance meaning. An element intended meaning (which produces by direct speech act) could in fact be delivered by several indirect speech acts. Grice is apprehensive with the diversity between what they said and the meaning. How did the speakers know how to produce this kind of implicit meanings, and how they argue that their performance will reliably catch their intended meaning? The goal is to find the mechanism behind the process.

A: Is there another pint of milk:

B: I'm going to the supermarket in five minutes.

From the example, the first speaker had a little trouble about inferring the meaning that the milk is used up. At the same moment, the second speaker said that he will buy it in a supermarket shortly.

Table 1. The Maxims of Conversations

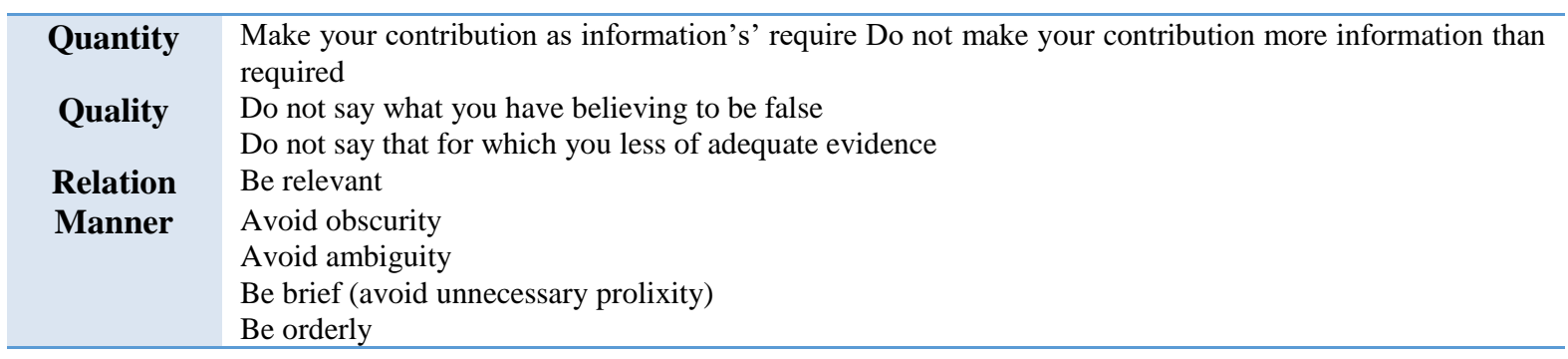

${ }^{\mathrm{a}}$ Grice (1957: 45-46)

Grice proposes that there is an occupancy way of speaking which we will accept as the behavior standard. At the time when an utterance was delivered, produced, or listened, generally it has information, relevant, and understandable. If utterances do not convey a non-sense information, the meaning is to be inferred.

The basic standards of explication in CP are Maxim and implicatures. At this point, cooperative principles used in language conveys various explanations. They are flouting, violating, infringing, and opting out. However, in the details provided by Grice, people often miss some ideas. Taylor and Cameron (1987:83) make a point that "some judges pause to think of the sundry kinds of Maxim which are subordinate to it". The total examples of flouts, violations, and opting out further explained the distinction between what they said and what they mean. An interest which is an evidence in the Gricean program since Grice (1957) and to show all about it, needs the pattern of interaction. The relationship between the conventional meaning of utterance and implicit meaning, may have been calculable. Grice (1957) does not mention that the interaction is "cooperative" in a sense that is found in the dictionary. In fact, as Davis (1997) mentioned, Grice principle argued that people cooperate in the communication process to reduce the misunderstanding point. In addition, Finch (2000:159) said that patterns in behavior lead the utterers to make the speech sounds more difficult for the hearers. The speakers convey their messages by limiting the number of utterances. The hearer calculates the utterance intention. It means that the CP is not in terms of making the task of hearer straightforward, potentially. It allowed the speaker to use the more difficult utterance than the easier. It means, the speaker can delete the information or the present non-literal utterance and hope that the hearer does more necessary work to the meaning. 


\section{Research Method}

The design of this research is qualitative research. The researcher used descriptive qualitative. It is qualitative because it deals with the natural phenomenon. Subroto (2007: 5) defines qualitative method is the method used to analyze the problems which are not designed or arranged using statistical procedure. Qualitative research focuses on understanding social phenomena from the view of the human participants in the research. Gay (2000:275) defines that the descriptive method is the useful method in investigating of various issue and problems in educational term. Moelong (2006:5) indicated that descriptive research is the research method that tries to explain the real object. The researcher uses this kind of design because it focused on the present phenomenon especially in a university environment. The data collecting technique is using the student's conversation in FB account.

\section{Findings and Discussion}

The research result shows that there are four types of maxim appeared in the group of FB interaction. The percentage was is calculated by dividing the total maxim of the conversation divided by the total number of maxim (40) and multiplied with 100 . However, the most frequent appearance was reached by maxim of quantity (seven utterances, or 15.2\%). Meanwhile, other maxims included maxim of quality, maxim of relevance, and maxim of manner, each uttered once $(2.2 \%)$. Further, the maxims were also violated during the interaction. Four violations included quantity ( 25 utterances, or $54.3 \%$ ), relevance (3 utterances, or $6.5 \%$ ), manner (8 utterances, or $17.3 \%$ ). Maxim of quality was not violated here. Table 2 can specifically show the utterances of maxims and violations.

Table 2.

The Utterances of Maxims and Violations

\begin{tabular}{|c|c|}
\hline MAXIM & EXAMPLES \\
\hline Quantity & $\begin{array}{l}\text { 1. I choose cell phone, the existence of cell phone right now is very important, it is completed by } \\
\text { several systems which make the users are able to enrich the knowledge and to communicate easily,,, } \\
\text { only by touching our fingers,, we can sit and see the world, internet can be reached also in our } \\
\text { phone,,,(LP.1). } \\
\text { I agree with u miss lusi. Because there are so many activities that we can do by using cell } \\
\text { phone.(RF.1) } \\
\text { Yeah. I choose a cell phone. You know. Cell phone as my soul mate?] (SA.1) } \\
\text { "Maybe you can go to my home Rika Kemala Candra hhe” (RF } \\
\text { When you late reply my message. .(SA) } \\
\text { "..Actually I learn for pragmatigs tomorrow. But. I'm so tired" (SA) } \\
\text { "..what is your topic dina". (YA) } \\
\text { "hopefully i can help you" (YA) } \\
\text { "Hihihihi. Same with me I can't drive a motorcycle. "(SA) }\end{array}$ \\
\hline Relevance & Why do you think like a clothes?? (RF.2) \\
\hline Manner & "Hello.. motorcycle or car???” (SA) \\
\hline $\begin{array}{l}\text { Violation of } \\
\text { Relevance }\end{array}$ & $\begin{array}{l}\text { coz it's totally complete ... I love browsing, doing works, even playing games in laptop.. (EC) } \\
\text { "How about your cellphone???” (SA) } \\
\text { "..coz u already made them agree with u about car.. but u prefer anather one now.. gasp emotikon" } \\
\text { (EC) }\end{array}$ \\
\hline
\end{tabular}


Violation of Quantity Maxim
Cellphone like our clothes maybe. RF.1)

It may be like someone who can help me everytime and everywhere (RF)

“...Or maybe. They didn't have a cell-phone”? (SF)

„, I still be able to leave my wallet at home but not my cellphone,, so you know it means,, (LP)

"...but because $i$ have low battery cellphone $n$ it often turns off because of the battery and you know.. i do not really like charging handphone grin emoticon." (EC)

"... i love to do my own routines with others in reality or face to face... if $i$ need cellp hone i'll go to dina's house directly.. hihihihi回” (RK)

"... i choose car, coz i can not ride motorcycle on road... coz i get butterfly in my stomach when somebody move faster around me? ? $(R K)$

" $U$ know.. $i$ seldom or take too long in replying ur bbm.. coz $i$ 'm busy with my laptop T,T Sofie Arandina"

yess kaka.. i love u driving a car.. u can pop me up... (EC)

"..i can not pop on my 5 children by motorcycle" (YA)

“... coz it very necessary n make our live more simple n easy" (RK)

"...my big apology darlaa.. coz so many things to do in new department that still have low data there.. may be u hav to send me message in FB grin emotikon." (EC)

“.... luv yuuuhhh回” (RK)

.. luv yuuuhhh? (EC

Anyway....

"..the same question beb squint emotikon" (EC)

"...my children always disturb me if i play hp" (RK)

"...Kak rina still focus in front of her laptop.. i guess, coz she is the first rank in our group so she needs to be clever than us.. wkwkwkwk." (RK)

"..badly needed when i want to have my research" (YA)

"..to have a strong justification" (YA)

“...You know. Metro-unila so far you know.][?]

“You know i can't drive motorcycle (-), (RF)

“..coz i can put many kinds of food for helping my basic needs" (RK)

The percentage of using maxim in the Flary conversation in FB (Facebook) can be seen in Table 3 below:

Table 3. The Percentage of Using Maxim in the Flary Conversation in Facebook

\begin{tabular}{|c|c|c|}
\hline No & Maxim & Percentage \\
\hline 1 & Quantity & $12.77 \%$ \\
\hline 2 & Quality & $1.05 \%$ \\
\hline 3 & Relevance & $4.3 \%$ \\
\hline 4 & Manner & $1.05 \%$ \\
\hline & Total & $19.17 \%$ \\
\hline
\end{tabular}

The percentage of failing using maxim in the Flary Conversation in Facebook can be seen in Table 4

Table 4.

The Percentage of Failing Using Maxim in the Flary Conversation in FB

\begin{tabular}{|c|c|c|}
\hline No & Violation of maxim & Percentage \\
\hline 1 & Quantity & $63.8 \%$ \\
\hline 2 & Quality & $10.63 \%$ \\
\hline 3 & Relevance & $4.3 \%$ \\
\hline \multirow[t]{2}{*}{4} & Manner & $2.1 \%$ \\
\hline & Total & $80.83 \%$ \\
\hline
\end{tabular}

The allegation of the finding result is relevant to the conversation in many kinds of manner. First, the cooperative principle is one of the main principles that guides the communication. Second, the goal of communication is to increase the competence of people communication and this principle has the strength effect in communication. Third, to work out the implication of conversation, it is important for the people because it can enrich their basic understanding of cooperative principles. The finding of this research shows that the cooperative principle can be applied to the conversation between the workmates and so on.

Violating the maxims happened of conversational above are: 
3.1.The Quantity in Maxims establishes the contribution as the information is required for the present aim of the change and does not establish the contribution more informative than the required. However, the speaker collides the quantity of maxim and summons the hearer to determine the meaning of the conversation by saying more (the explanation of more information) or (less providing information) than is required. Such this conversation:

Sofie Arandina For me. Of course.. I choose Car???

You know. Metro-unila so far you know.

3.2.The quality of Maxim needs us not to mention what we believe to be false and what we less adequate of proof. In this interaction, it can be seen in this conversation:

Reza Fandana I think I have to learn like mrs rina does

Suka $\cdot$ Balas $\cdot 22$ April pukul 21:25

3.3. Maxim of quality (because it is the fact that mrs rina always study) and quantity because the utterance is not around only talk that is required.

3.4. The relation in maxim shows that the speakers' utterance is not relevant to the meaning of context for some excuse. The implication of the conversation is produced by violation of the maxim relation. The speaker may not mention anything in explicit related to the theme but it asked the hearer to look for the translation of the possible meaning. The example used to analyze the implication of the conversation produced by the violation in maxim relation. For the example :

Esy CHan wahaha...you r all addicted by cellphone.. I Love too but because $i$ have low battery cellphone $n$ it often turns off because of the battery and you know.. $i$ do not really like charging handphone grin emotikon

Suka $\cdot$ Balas $\cdot 22$ April pukul 21:08

3.5. Violation of quantity maxim.

Sofie Arandina Esy CHan How about your cellphone???

Suka $\cdot$ Balas $\cdot 22$ April pukul 21:08

3.6. Violation of relevance, because Esy chan has mentioned her cell phone before but Sofie Aandina response to it by asking her again.

3.7. The violation manner of the maxim is giving unclear and ambiguous information for the hearer. Here, it is analyzed how the example violates the manner of the maxim which offers rise to the implication of conversation. Here is the example.

Sofie Arandina So guys. How about two thing.???

Suka $\cdot$ Balas $\cdot 22$ April pukul 21:35

The example was included as violation of manner maxim because it is not clear question.

\section{Conclusion}

The cooperative principle is one of the main principles in guiding the communication. This principle and the maxim could neatly explain what the original meaning and its implication in the communication process is. The use of cooperative principle in communication shows that it could be conducive to improve the competence of communication. Even though there are many violations in the interactions, the conversations still run well but when the speakers realize the cooperative principle, the conversation will be more understandable, effective, and efficient.

\section{References}

Austin, J.L. (1962). How to do things with words. London: Oxford University Press.

Davis, J.N. \& Lyman-Hager, M.A. (1997). Computers and 12 reading: Student performance, student attitudes. Foreign Language Annals, 30(1), 58-72.

Finch, G. (2000). Linguistic terms and concepts. New York Palgrave Macmillan.

Gay, L.R and Petter, A. (2000). Education research competencies for analysis and aplication. Prentice-Hall, Inc. 
Grice, H. P. (1957). The Philosophical Review, 66(3), 377-388.

Moloeng, L.J. (2006). Metode penelitian kualitatif. Bandung: PT Remaja Rosdakarya.

Searle, J.R. (1969). Speech act: An essay on the philosophy of language. New. York: Cambridge University Press.

Subroto, E. (2007). Pengantar metode penelitian linguistik struktural. Surakerta: Lembaga Pengembangan Pendidikan. Universitas Sebelas Maret.

Taylor, T.J., \& Cameron, D. (1987). Analysing conversation: Rules and units in the structure of talk. Oxford: Pergamon Press. 